\title{
Peningkatan Derajat Kesehatan Masyarakat Melalui Pemeriksaan Kesehatan Dan Edukasi Pola Hidup Sehat
}

\author{
Puspitasari $^{1}$, Evi Rinata ${ }^{2}$, Agus Salim $^{3}$ \\ Universitas Muhammadiyah Sidoarjo ${ }^{1,2,3}$ \\ puspitasari@umsida.ac.id ${ }^{1}$,evi.rinata@umsida.ac.id ${ }^{2}$, disorder_salim@yahoo.com ${ }^{3}$
}

\begin{abstract}
Improving the level of public health can be started by increasing sufficient knowledge about healthy lifestyles. The period of the elderly is a period of life that needs attention because this period is susceptible to disease. Community service activities aim to broaden the views on the importance of health for the elderly. This activity was carried out at the elderly Posyandu, Jiken Village, Tulangan, Sidoarjo in March to April 2019. The method used was observation, Point of Care Testing (POCT) training for Posyandu cadres, counseling and consultation regarding healthy lifestyles. The result of this activity is that Posyandu cadres can do Point of Care Testing (POCT) and can implement it continuously because the simple medical devices they have are complete.In addition, the elderly people are increasingly enthusiastic to come to the posyandu. This can be seen from the list of visits and activeness of the elderly in participating in the whole series of activities while in the posyandu.
\end{abstract}

Keywords: Public health; Posyandu; Elderly

\begin{abstract}
Abstrak
Peningkatan derajat kesehatan masyarakat dapat dimulai dengan meningkatkan pengetahuan yang cukup mengenai pola hidup sehat. Periode lansia merupakan periode kehidupan yang perlu mendapatkan perhatian karena pada periode ini rentan terhadap penyakit.Kegiatan pengabdian masyarakat bertujuan untuk memperluas pandangan tentang pentingnya kesehatan bagi lansia. Kegiatan ini dilaksanakan di Posyandu lansia Desa Jiken Kecamatan Tulangan Kabupaten Sidoarjo pada bulan Maret sampai dengan April 2019. Metode yang digunakan yaitu mulai dari observasi, pelatihan Point of Care Testing (POCT) bagi kader posyandu, penyuluhan dan konsultasi terkait pola hidup sehat serta konseling. Hasil dari kegiatan ini adalah kader posyandu lansia dapat melakukan Point of Care Testing (POCT) dan dapat menerapkannya secara berkelanjutan karena alat kesehatan sederhana yang dimiliki sudah cukup lengkap. Selain itu, masyarakat lansia semakin antusias untuk datang ke posyandu. Hal ini terlihat dari daftar kunjungan dan keaktifan lansia dalam mengikuti seluruh rangkaian kegiatan selama berada di posyandu mulai dari registrasi, senam lansia, sampai dengan pemeriksaan kesehatan secara rutin.
\end{abstract}

Kata Kunci: Kesehatan masyarakat; Posyandu; Lansia 


\section{A. PENDAHULUAN}

Posyandu lansia merupakan fasilitas layanan kesehatan yang berada di desa bertujuan untuk meningkatkan kesehatan masyarakat khususnya usia lanjut. Posyandu lansia adalah pengembangan dari kebijakan pemerintah yang penyelenggaraannya melalui program Puskesmas dengan melibatkan peran serta masyarakat lansia, keluarga, tokoh masyarakat, maupun organisasi sosial (Efendi, 2009).

Badan Pusat statistik memprediksi, jumlah penduduk usia lanjut akan semakin meningkat menjadi 27,1 juta jiwa pada tahun 2020, dan meningkat menjadi 33,7 juta jiwa pada tahun 2035 (Permenkes RI, 2016).

Permasalahan yang sering dihadapi oleh usia lanjut yaitu keterbatasan fisik dan kerentanan terhadap penyakit. Dengan bertambahnya usia akan dapat menyebabkan terjadinya perubahan degeneratif dengan manifestasibeberapa penyakit diantaranya hipertensi, kelainan jantung, penyakit diabetes mellitus, kanker rahim/prostat, osteoporosis dan lain-lain (Depkes RI, 2003). Beberapa masyarakat beranggapan bahwa usia lanjut merupakan hal yang alami dan biasa bila lansia sering sakit, cepat marah. Dengan anggapan seperti itu seringkali kesehatan lansia tidak tertangani.

Pemerintah berupaya untuk menjaga kesehatan bagi lansia dengan menjamin ketersediaan fasilitas pelayanan kesehatan dan memfasilitasi kelompok lansiaseperti puskesmas (UU RI, 2009). Akan tetapi, lansia sendiri kurang dapat memanfaatkan pelayanan kesehatan yang ada karena jarak yang cukup jauh. Oleh karena itu posyandu lansia merupakan salah satu wujud upaya untuk menangani kesehatan masyarakat usia lanjut.

Saat ini tidak semua lansia mengikuti kegiatan posyandu. Hal ini dikarenakan beberapa faktor, diantaranya yaitu umur, pendidikan, pekerjaan, pendapatan, sumber daya kesehatan, fasilitas, dukungan masyarakat (Purnawati, 2014).. Kurangnya dukungan keluarga juga dapat mengakibatkan lansia enggan untuk datang ke posyandu (Sundari, 2012). Kendala lainnya antara lain pengetahuan yang rendah tentang manfaat posyandu, jarak rumah dengan tempat posyandu, sikap kader yang kurang baik, serta monotonnya kegiatan yang ada ( Maryati, 2013; Mengko, 2015).

Posyandu lansia di Desa Jiken memiliki 2 pos yaitu pos 1 yang dilaksanakan di Balai Desa Jiken dan pos 2 yang dilaksanakan di gedung olahraga. Hal ini dikarenakan desa Jiken terdiri dari 2 dusun yaitu Dusun Jiken dan Dusun Bringin. Sasaran Posyandu lansia yang ada di Desa Jiken Kecamatan Tulangan Kabupaten Sidoarjo yaitu warga desa yang berusia diatas 50 tahun.

Pada pos 1 posyandu dilaksanakan di balai desa setiap hari senin minggu kedua setiap bulannya. Sedangkan pada pos 2 , posyandu dilaksanakan di gedung olahraga desa Jiken setiap hari kamis minggu kedua setiap bulannya.

Permasalahan yang dihadapi oleh posyandu lansia desa Jiken antara lain yaitu kegiatan yang seharusnya dilaksanakan belum sepenuhnya diterapkan seperti edukasi, konseling, konsultasi pola hidup sehat, dan pemeriksaan kesehatan (pemeriksaan laboratorium sederhana) secara rutin. Hal ini dikarenakan keterbatasan dari alat kesehatan dan kemampuan dari sumber daya manusia, dalam hal ini kader posyandu.

Berdasarkan hal tersebut maka kami menawarkan solusi untuk mengembangkan kegiatan posyandu berupapenyediaan alatalat pemeriksa kesehatan sederhana seperti tensi meter, senter medis, alat pengukur tinggi badan, alat pengukur berat badan, alat ukur glukosa, kolesterol, dan asam urat 
dalam darah untuk mengontrol kesehatan lansia secara rutin.

Pelatihan dalam melakukan pemeriksaan dasar seperti pemeriksaan kadar glukosa darah, kolesterol, dan asam urat darah juga bdiberikan kepada kader kesehatan di posyandu lansia, sehingga dapat dilakukan secara rutin setiap kali dilaksanakannya posyandu lansia dan tidak lagi menunggu kunjungan dari puskesmas.

Penyediaan poster kesehatan untuk sarana edukasi dan konseling bagi masyarakat lansia juga tidak kalah pentingnya. Poster dapat dipamerkan ditempat posyandu, sehingga dapat dilihat dan dibaca oleh pengunjunguntuk menambah pengetahuan tentang pola hidup sehat di usia lanjut dengan dipandu oleh kader kesehatan yang sudah dilatih.

Dalam kegiatan pengabdian masyarakat ini juga diberikan fasilitas konsultasi terkait pola hidup sehat bagi lansia baik secara fisik maupun psikis (konseling) serta penyuluhan dengan tema kesehatan.

\section{B. PELAKSANAAN DAN METODE}

Dalam kegiatan ini kami memberikan edukasi berupa penyuluhan dan menyampaikan pesan-pesan menggunakan media poster serta banner kepada masyarakat khususnya usia lansia untuk dapat menjalankan pola hidup yang sehat. Selain itu kami juga memberikan konseling terkait kesehatan psikis. Dengan adanya edukasi yang didapatkan oleh masyarakat, diharapkan mereka dapat menjaga kesehatan dan mengantisipasi risiko yang ditimbulkan akibat suatu penyakit.

Suatu penyakit dapat diketahui dengan adanya suatu pemeriksaan kesehatan, sehingga pada kegiatan yang kami lakukan tidak hanya memberikan edukasi tetapi juga memberikan pemeriksaan kesehatan secara gratis untuk dapat mengetahui kondisi kesehatan masyarakat lansia yang ada di desa Jiken. Pemeriksaan kesehatan meliputi pemeriksaan tekanan darah, glukosa, kolesterol, dan asam urat dalam darah.

Kegiatan ini juga melatih kader kesehatan/posyandu untuk dapat melakukan Point of Care Testing (POCT) untuk pemeriksaan glukosa darah, asam urat, dan kolesterolbagi lansia, sehingga dapat diterapkan secara rutin dan berkelanjutan dengan inovasi-inovasi kegiatan yang tidak monoton.

\section{C.HASIL DAN PEMBAHASAN}

Kegiatan ini diselenggarakan pada bulan Maret sampai dengan bulan April 2019. Pengabdian masyarakat dilakukan di 2 posyandu lansia yang ada di Desa Jiken. Kegiatan ini dimulai dengan penyediaan sarana berupa alat-alat kesehatan dasar dan instrumen promosi kesehatan yang dibutuhkan oleh posyandu lansia. Sarana tersebut diserahkan kepada kepala Desa Jiken pada tanggal 29 Maret 2019 untuk dapat dimanfaatkan dalam memberikan pelayanan kesehatan bagi lansia.

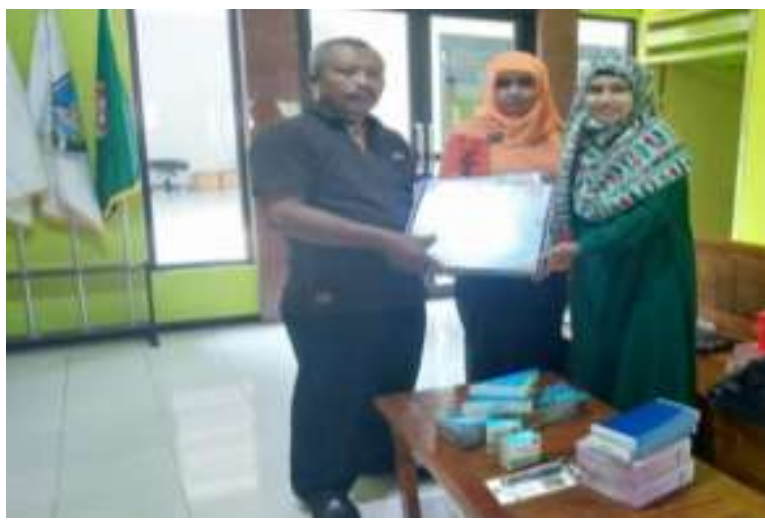

Gambar 1. Penyerahan sarana penunjang posyandu lansia

Pada tahap awal, tim pengabdian masyarakat melakukan pemasangan poster promosi kesehatan tentang pencegahan 
tekanan darah tinggi yang meliputi faktor penyebab, gejala yang ditimbulkan, serta cara mencegahnya. Selain itu juga kami memasang poster tentang Osteoporosis yang meliputi faktor risiko osteoporosis dan cara pencegahannya. Poster tersebut didesain dengan memperhatikan warna, gambar, dan tulisan. Warna huruf yang kontras dengan backgrounddapat lebih mudah untuk dibaca (Anitah, 2009). Selain itu poster dipasang ditempat yang strategis sehingga dapat menumbuhkan keinginan orang untuk membacanya (Iversen dkk, 2007).

Pada saat posyandu lansia berlangsung, kegiatan pertama yang dilakukan setelah peserta hadir adalah melakukan registrasi dengan menunjukkan kartu anggota lansia serta Kartu Menuju Sehat (KMS) Lansia. Contoh Kartu Tanda Anggota Lansia Desa Jiken ditampilkan pada Gambar 2.

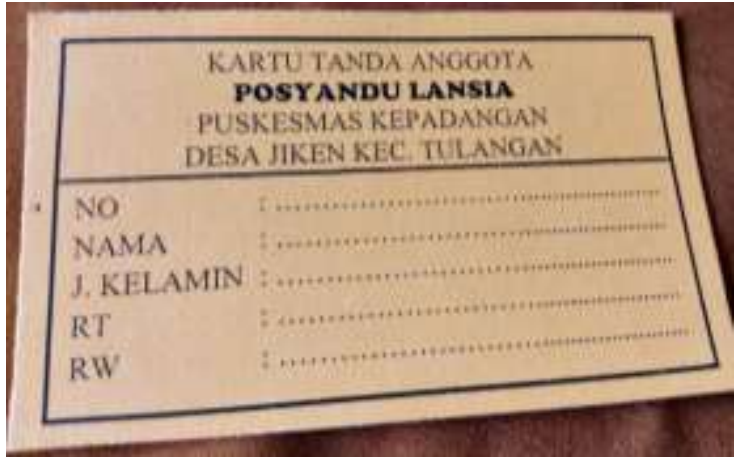

Gambar 2. Kartu Tanda Anggota Lansia Desa Jiken

Setelah itu dilakukan pengukuran berat badan dan tinggi badan. Pengukuran berat badan lansia ditampilkan pada Gambar 3. Kemudian, lansia berkumpul untuk mengikuti senam lansiadengan dipandu oleh instruktur yang sudah berpengalaman. seperti yang ditunjukkan pada Gambar 4.

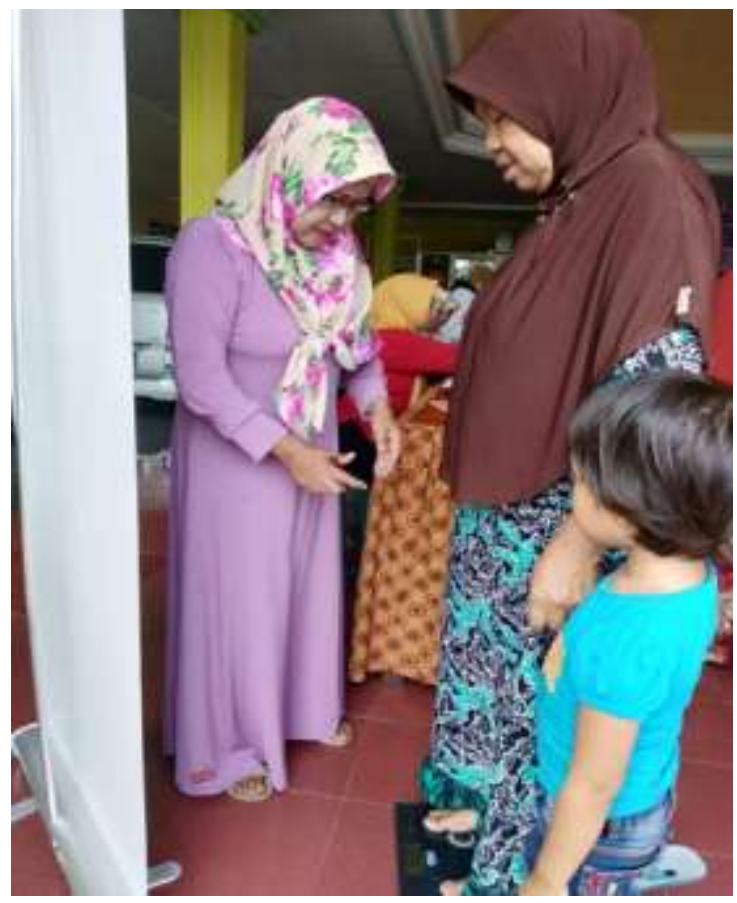

Gambar 3. Pengukuran berat badan

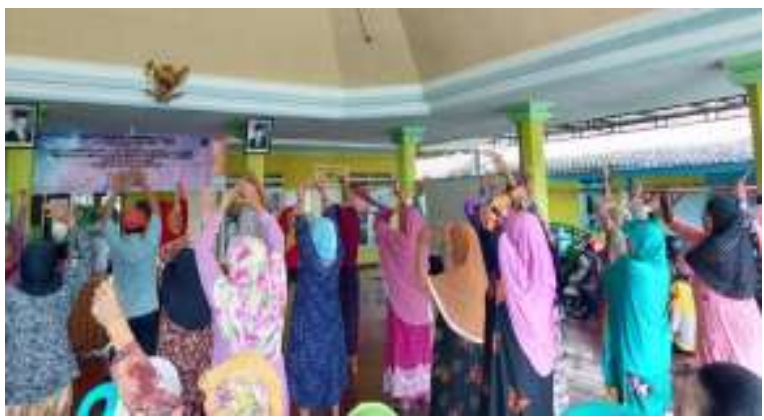

Gambar 4. Senam lansia

Kegiatan berikutnya yaitu memberikan pelayanan pemeriksaan gratis yang meliputi pemeriksaan glukosa darah, asam urat, dan kolesterol bagi lansia. Kegiatan ini dilaksanakan pada tanggal 08 April 2019 bertempat di pos 1 yaitu Balai Desa Jiken dengan jumlah peserta sebanyak 81 orang dan dilaksanakan pada tanggal 11 April 2019 di pos 2 yaitu gedung olahraga Desa Jiken dengan peserta berjumlah 48 orang.

Masyarakat sangat antusias sekali ingin mengetahui kondisi kesehatannya. Walaupun sebelumnya ada yang takut untuk 
diperiksa darahnya, tapi hal ini dapat diselesaikan dengan cara diberikan penjelasan serta dukungan baik dari tim pengabdian masyarakat maupun dari kader kesehatan. Pada tahap ini kader juga dilatih untuk dapat memberikan pelayanan POCT untuk pemeriksaan glukosa darah, asam urat, dan kolesterolpada lansiasehingga dapat diterapkan secara berkelanjutan.

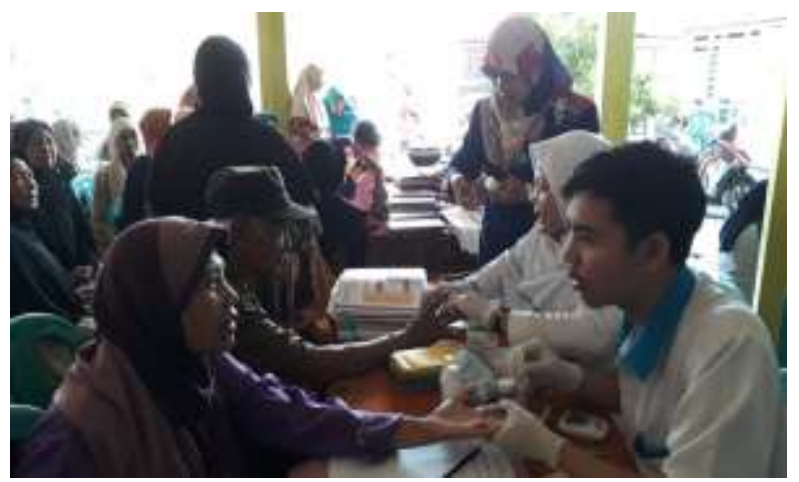

Gambar 5. Pemeriksaan kesehatan gratis yang dilakukan oleh tim pengabdian masyarakat

Kegiatan berikutnya adalah penyuluhan yang dilaksanakan pada tanggal 11 April 2019 di Gedung olahraga desa Jiken dengan. Berdasarkan hasil wawancara dengan beberapa lansia, mereka merasa senang karena pengetahuan mereka menjadi bertambah dan menjadi sadar akan pentingnya hidup sehat.

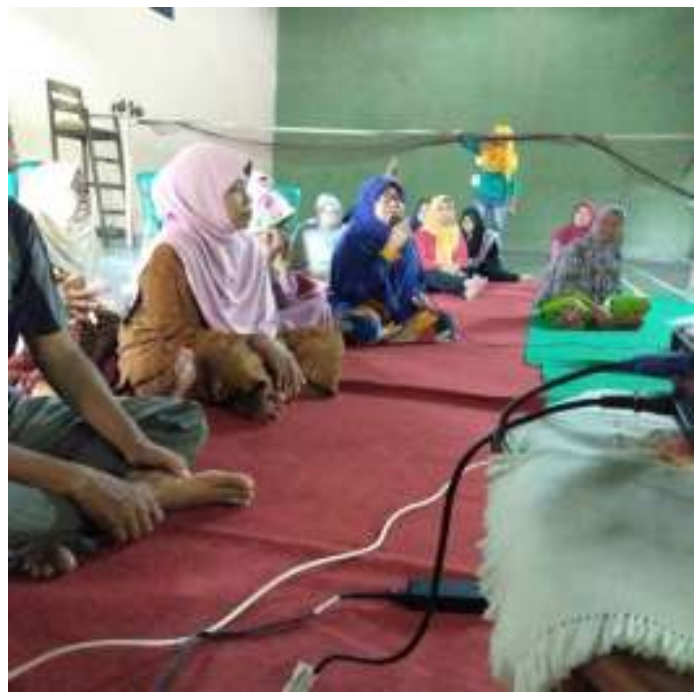

Gambar 6. Sesi tanya jawab saat penyuluhan

Dari Gambar 6, menunjukkan rasa ingin tahu lansia Desa Jiken masih tinggi. Beberapa pertanyaan disampaikan kepada pemateri, sehingga terjadi diskusi yang sangat menarik selama kegiatan penyuluhan berlangsung.

Konsultasi terkait psikologis juga diberikan selama pengabdian masyarakat berlangsung baik di pos 1 maupun pos 2 . Hal ini juga merupakan kegiatan yang belum pernah ada sebelumnya, sehingga lansia memanfaatkan adanya fasilitas konseling ini. Konseling yang dilakukan oleh salah satu tim pengabdian masyarakat dapat dilihat pada Gambar 7.

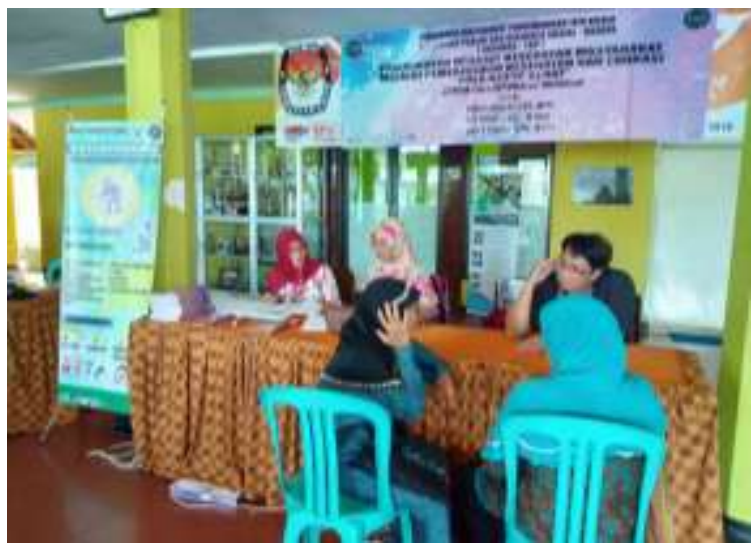

Gambar 7. Fasilitas layanan konseling bagi lansia 
Dengan adanya pengembangan kegiatan pada posyandu lansia di Desa Jiken, membuat lansia lebih termotivasi dan tidak bosan untuk datang ke posyandu sehingga kesehatan mereka dapat dipantau secara rutin setiap bulannya.

\section{PENUTUP}

\section{Simpulan}

Dari kegiatan ini dapat disimpulkan bahwa terdapat kontribusi yang positif dalam rangka peningkatan derajat kesehatan masyarakat khususnya lansia di Desa Jiken Kecamatan tulangan, Kabupaten Sidoarjo. Penyediaaan alat-alat kesehatan, pelatihan, penyuluhan, serta konseling dapat meningkatkan kepuasan bagi lansia berserta keluarganya. Selain itu masyarakat semakin sadar akan pentingnya kesehatan. Dengan berawal dari posyandu, maka kesehatan lansia dapat terpantau secara berkala dan secara tidak langsung dapat meningkatkan umur harapan hidup masyarakat yang ada di Desa Jiken.

\section{Saran}

Mitra dalam hal ini yaitu Desa Jiken Kecamatan Tulangan Kabupaten Sidoarjo, diharapkan dapat meningkatkan kualitas pelayanan posyandu khususnya posyandu lansia dengan menyelenggarakan kegiatankegiatan yang lebih menarik yang dapat mendukung aktifitas kesehatan lansia sehingga kesehatan lansia di Desa Jiken dapat meningkat.

\section{Ucapan Terima Kasih}

Terimakasih kami sampaikan kepada Universitas Muhammadiyah Sidoarjo atas pendanaan pengabdian masyarakat tata kelola kehidupan publik dan rekayasa sosialbudaya untuk tahun anggaran 2019. Ucapan terimakasih juga kami sampaikan kepada Kepala Desa, Ketua posyandu Lansia, dan kader kesehatan Desa Jiken Kecamatan Tulangan, Kabupaten Sidoarjo yang telah membantu dalam kegiatan ini.

\section{E. DAFTAR PUSTAKA}

Anitah S. 2009. Media Pembelajaran. Yuma Presindo, Surakarta.

Depkes RI. 2003. Pedoman Pemantauan dan penilaian Program Kesehatan Usia Lanjut bagi Petugas Kesehatan. Buni Kesehatan Masyarakat, Departemen Kesehatan, Jakarta.

Efendi. 2009. Keperawatan Kesehatan Komunitas. Salemba, Jakarta

Iversen MK, Handeli MN and Jensen EN. 2007. Effect of health-promoting posters placed on the platform of two train stations in Copenhagen, Denmark, on the choice between taking the stairs or the escalators: a secondary publication. International Journal of Obesity. 31: 950-955.

Maryati H, Fatoni A dan T Hexawan. 2013. Gambaran faktor-faktor yang mempengaruhi Lansia tidak mengikuti posyandu lansia di Posyandu Dahlia di 2 Dusun Ngabar Desa Sumber teguh kecamatan Kudu Kabupaten Jombang tahun 2013. Jurnal Metabolisme. $2(3)$.

Mengko VV, Kandou GD, Massie RGA. 2015. Pemanfaatan Posyandu Lansia di Wilayah Kerja Puskesmas Teling Atas Kota Manado. Jurnal Ilmu Kesehatan Masyarakat Universitas Sam Ratulangi Manado. 5(2b) 
Peraturan Menteri Kesehatan Republik Indonesia Nomor 25 Tahun 2016 Tentang Rencana Aksi Nasional Kesehatan Lanjut Usia Tahun 2016 2019.

Purnawati N. 2014. Faktor-faktor yang mempengaruhi kunjungan lansia dalam kegiatan Posyandu di Desa Plumbon Kecamatan Mojolaban Sukoharjo. Skripsi. Universitas Muhammadiyah Surakarta.

Sundari S dan Mentari P. 2012. Faktor-faktor yang berhubungan dengan keikut sertaan dalam Posyandu Lansia. Akademi Kebidanan Ummi Khasanah, Bantul.

Undang-Undang Republik Indonesia Nomor 36 Tahun 2008 Tentang Kesehatan. 